\title{
Changes in the Blood Components Caused by Water Intake
}

\author{
Hyun-Kyung Kim, Soo-Hwan Kim, Jae-Ki Ryu \\ Department of Biomedical Laboratory Science, College of Natural Science, Gimcheon University, Gimcheon, Korea
}

\section{물 섭취에 의한 혈액 성분 변화에 관한 연구}

\author{
김현경, 김수환, 류재기 \\ 김천대학교 임상병리학과
}

\begin{abstract}
Although water is an essential component of the human body and is involved in many physiological processes, the effect of a steady and sufficient water intake on blood components has not well elucidated. Therefore, we investigated the changes in hematological parameters, high-sensitivity C-reactive protein (hs-CRP), and immunoglobulin G (IgG) after water intake in 13 healthy adults. They were divided into two groups: The control group $(\mathrm{N}=4)$, which consumed water ad libitum, and the experimental group ( $\mathrm{N}=9$ ), which consumed $2 \mathrm{~L}$ of water per day. Two weeks later, blood cell counts, hematocrit, and hemoglobin content had increased in the experimental group, although not significantly $(p>0.05)$; however, there was a significant increase in the mean corpuscular hemoglobin $(\mathrm{MCH})$ and mean corpuscular hemoglobin concentration $(\mathrm{MCHC})(p<0.05$; and $p$ $<0.01$, respectively), and a significant decrease in the mean platelet volume (MPV) $(p<0.05)$. Of the immunologic parameters, a non-significant decrease in the concentration of hs-CRP, an indicator of cardiovascular disease risk, was observed $(p>0.05)$. However, there was a dramatic and significant increase in the concentration of $\operatorname{lgG}(p<0.05)$. In conclusion, a steady and sufficient water intake may contribute to alleviate anemia by increasing hemoglobin. Additionally, it may decrease the risk of cardiovascular disease by decreasing platelet activation and concentration of hs-CRP. Furthermore, a steady intake of water may improve immune function by increasing the concentration of the components of humoral immunity.
\end{abstract}

Key words: Hemoglobin, High-sensitivity C-reactive protein, IgG, Mean platelet volume, Water

This is an Open Access article distributed under the terms of the Creative Commons Attribution Non-Commercial License (http://creativecommons.org/licenses/by-nc/4.0) which permits unrestricted non-commercial use, distribution, and reproduction in any medium, provided the original work is properly cited

Copyright @ 2017 The Korean Society for Clinical Laboratory Science. All rights reserved.
Corresponding author: Jae-Ki Ryu Department of Biomedical Laboratory Science, College of Natural Science, Gimcheon University, 214 Daehak-ro, Gimcheon 39528 Korea

Tel: 82-54-420-4041

Fax: 82-54-420-4461

E-mail: rs0429@hanmail.net

Received: July 28, 2017

Revised 1 ${ }^{\text {st. }}$ : August 23, 2017

Revised 2 ${ }^{\text {nd }}$ : August 25, 2017

Accepted: August 25, 2017

\section{INTRODUCTION}

Blood is composed of cells and plasma. Blood cells comprise white blood cells (WBCs), red blood cells (RBCs), and platelets, the numbers of which vary according to physiological and pathological conditions [1]. Plasma is composed mostly of water and contains dissolved proteins, lipids, glucose, and hormones. The various components dissolved in the plasma control the body's immunological and biochemical activities [1]. A hematology analyzer is commonly used to investigate changes in hematological parameters, which vary in response to systemic changes. These hematological parameters include WBCs, which defend the body against foreign invaders; their numbers increase during inflammation. RBCs contain hemoglobin, which carries oxygen to the tissues. When an individual 
has anemia, there is a decrease in the RBC count, hemoglobin level and other related parameters, such as mean corpuscular hemoglobin (MCH) and mean corpuscular hemoglobin concentration (MCHC). Platelets have a hemostatic function. During injury, they gather at the site of damage in blood vessels and form a primary platelet plug. Bleeding occurs when the platelet count decreases [1]. The mean platelet volume (MPV) is an indicator of platelet size and platelet activation [2,3].

Infection induces sickness via cytokine-induced inflammation [4]. Self-rated health (SRH) is widely used as a subjective assessment of health status. Shanahan et al., reported that poor SRH is associated with elevated high sensitivity C-reactive protein (hs-CRP) in young adults [5]. C-reactive protein (CRP) is an innate recognition protein and a sensitive marker of inflammation; associations have been found between low CRP levels and good health in men [6]. In addition to being a useful biomarker of inflammation, hs-CRP is used to assess the risk of cardiovascular disease (CVD) [7].

Immunoglobulin $\mathrm{G}(\mathrm{Ig} G)$ is a glycoprotein and a major serum immunoglobulin. It plays a role in humoral immunity in recognizing, neutralizing, and eliminating foreign invaders. IgG is the main antibody in the blood and the serum IgG fraction is the major component of intravenous immunoglobulin G (IVIG) preparation [8]. In addition, IgG mediates anti-inflammatory activity through interaction of its Fc fragment with Fcy receptors [9].

Water is an essential component of the human body and constitutes $55 \sim 75 \%$ of the total body mass. It plays an important role in many physiological processes and affects an individual's health $[10,11]$. However, the effects of a steady and sufficient intake of water on hematological parameters and blood components are not well known. In this study, we measured changes in hematological parameters, hs-CRP, and IgG caused by water intake, and investigated the effects of water on health.

\section{MATERIALS AND METHODS}

\section{Subjects}

Participants recruited in autumn 2015 through printed advertisements on notice boards at Gimcheon University, were healthy adult university students with no known medical condition, ranging in age from 20 to 26 years. Each participant signed a consent form confirming agreement to participate in this study. Thereafter, they were allocated to the control or experimental group.

\section{Methods}

At baseline, we measured $\mathrm{WBC}, \mathrm{RBC}$, and platelet counts; performed assays of hematocrit, $\mathrm{MCV}, \mathrm{MCH}$, $\mathrm{MCHC}, \mathrm{MPV}$, and hemoglobin; and determined hs-CRP, and IgG levels for each participant. The control group consumed water ad libitum, whereas the experimental group consumed $2 \mathrm{~L}$ of commercial water per day. Participants were advised to continue their usual food intake during the study period. Two weeks later, we repeated the baseline assays and analyzed changes in blood components in both groups. Hematological parameters were measured using an $\mathrm{HeCo} \mathrm{C}$ hematology analyzer (Seac-Radim, Rome, Italy). The hs-CRP assay was performed using a Cobas ${ }^{\circledR} 8000$ c702 modular analyzer (Roche Diagnostics Limited, Basel, Switzerland). IgG levels were assessed using a Cobas Integra ${ }^{\circledR} 800$ analyzer (Roche Diagnostics Limited, Basel, Switzerland).

\section{Statistical analysis}

The statistical analysis was performed using GraphPad Prism 5 software (GraphPad Software Inc., San Diego, CA, USA). Wilcoxon signed-rank test, a statistical test of non-parametric paired data, was performed to evaluate whether the difference between pre- and post-water intake was significant. 


\section{RESULTS}

1. A steady intake of water increases hemoglobin indices, such as the $\mathrm{MCH}$ and $\mathrm{MCHC}$, and decreases the MPV

As shown in Table 1, at the end of the study period, $\mathrm{WBC}, \mathrm{RBC}$, and platelet counts increased in the experimental group, as did hematocrit and hemoglobin levels, although the increases were not significant $(p>$ 0.05). Moreover, there were significant increases in $\mathrm{MCH}$ levels and $\mathrm{MCHC}(p<0.05, p<0.01$, respectively). However, the MPV decreased significantly in the experimental group $(p<0.05)$.

\section{A steady intake of water decreases the concentration of hs-CRP}

At the end of the study period, the concentration of hs-CRP had decreased in the experimental group, although the decrease was not significant $(p>0.05)$ (Figure 1).

\section{A steady intake of water increases the concentration of IgG}

To investigate the effects of water intake on humoral immunity, we determined changes in the level of IgG before and after water in each group. The levels of $\mathrm{IgG}$ in the experimental group had increased significantly by the

\section{High-sensitivity CRP}

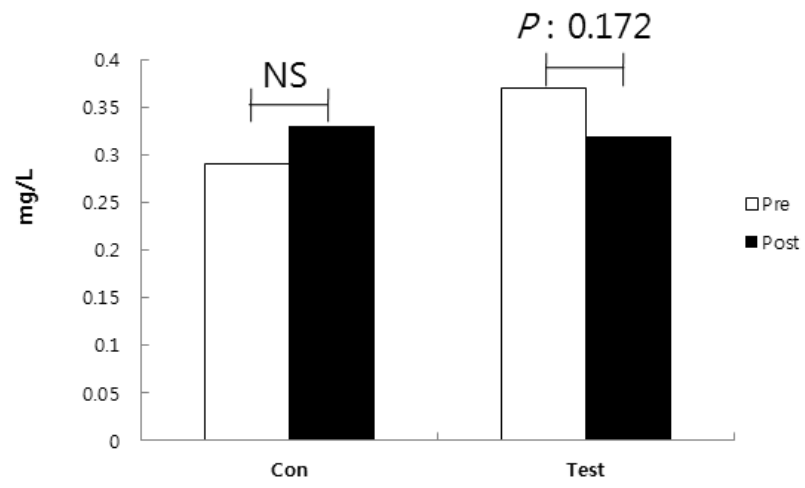

Figure 1. Changes in high-sensitivity C-reactive protein (hs-CRP) in the blood after water intake. pre: before water intake, post: after water intake. The wilcoxon signed rank test was used for statistical analysis. $p<0.05$ : statistically significant, NS, not significant; Con, control group.

Table 1. Changes in hematologic parameters after water intake

\begin{tabular}{|c|c|c|c|c|c|c|c|c|}
\hline & \multicolumn{4}{|c|}{ Experimental group $(\mathrm{N}=9)$} & \multicolumn{4}{|c|}{ Control group $(\mathrm{N}=4)$} \\
\hline & & Mean & SD & $p$-value & & Mean & SD & $p$-value \\
\hline \multirow[t]{2}{*}{ WBC $\left(\times 10^{3} / \mu \mathrm{L}\right)$} & Pre & 6.625 & 1.858 & 0.779 & Pre & 6.4 & 1.48 & 0.625 \\
\hline & Post & 6.975 & 1.512 & & Post & 6.63 & 1.95 & \\
\hline \multirow[t]{2}{*}{$\mathrm{RBC}\left(\times 10^{6} / \mu \mathrm{L}\right)$} & Pre & 4.609 & 0.286 & 0.820 & Pre & 4.533 & 0.344 & 0.625 \\
\hline & Post & 4.792 & 0.518 & & Post & 4.78 & 0.342 & \\
\hline \multirow[t]{2}{*}{$\mathrm{Hgb}(\mathrm{g} / \mathrm{dL})$} & Pre & 11.663 & 1.572 & 0.213 & Pre & 10.67 & 2.4 & 1.000 \\
\hline & Post & 12.238 & 1.38 & & Post & 10.9 & 2.59 & \\
\hline \multirow[t]{2}{*}{ Hct $(\%)$} & Pre & 40.39 & 4.26 & 1.000 & Pre & 37.37 & 6.57 & 1.000 \\
\hline & Post & 41.84 & 5.16 & & Post & 39.53 & 8.04 & \\
\hline \multirow[t]{2}{*}{$M C V(f L)$} & Pre & 87.88 & 8.98 & 0.766 & Pre & 83.67 & 12.34 & 0.424 \\
\hline & Post & 87.63 & 8.88 & & Post & 82.67 & 12.34 & \\
\hline \multirow[t]{2}{*}{$\mathrm{MCH}(\mathrm{pg})$} & Pre & 25.65 & 3.38 & 0.014 & Pre & 24.43 & 4.91 & 1.000 \\
\hline & Post & 26.54 & 3.34 & & Post & 24.67 & 4.79 & \\
\hline \multirow[t]{2}{*}{$\mathrm{MCHC}(\mathrm{g} / \mathrm{dL})$} & Pre & 28.925 & 1.108 & 0.008 & Pre & 28.667 & 1.62 & 1.000 \\
\hline & Post & 30.1 & 0.989 & & Post & 29.067 & 1.266 & \\
\hline \multirow[t]{2}{*}{ Plt $\left(\times 10^{5} / \mu \mathrm{L}\right)$} & Pre & 2.913 & 0.611 & 0.779 & Pre & 3.063 & 0.431 & 0.250 \\
\hline & Post & 2.941 & 0.713 & & Post & 2.87 & 0.416 & \\
\hline \multirow[t]{2}{*}{ MPV (fL) } & Pre & 11.175 & 0.723 & 0.018 & Pre & 11.567 & 0.493 & 1.000 \\
\hline & Post & 10.95 & 0.687 & & Post & 11.6 & 0.529 & \\
\hline
\end{tabular}

The wilcoxon signed rank test was used for statistical analysis, pre: before water intake, post: after water intake. $p<0.05$ : statistically significant.

SD, standard deviation; WBC, white blood cell; RBC, red blood cell; Hgb, hemoglobin; Hct, hematocrit; MCV, mean corpuscular volume; $\mathrm{MCH}$, mean corpuscular hemoglobin; Plt, platelet; MPV, mean platelet volume. 


\section{Immunoglobulin $\mathbf{G}$}

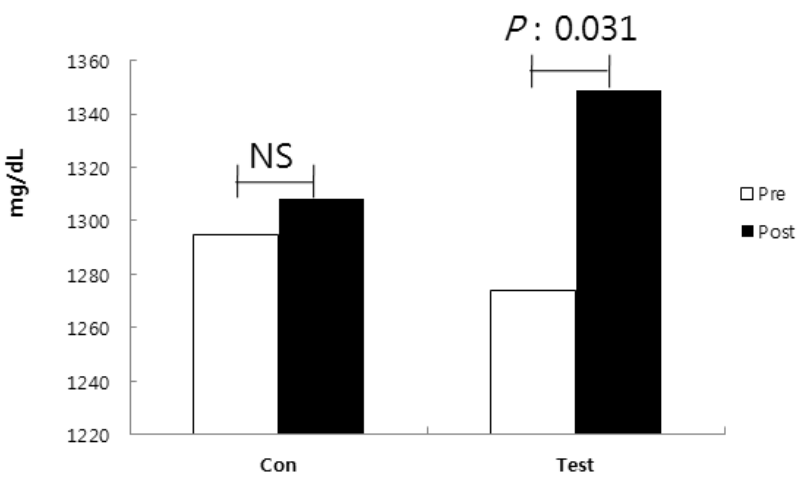

Figure 2. Changes in immunoglobulin $\mathrm{G}(\mathrm{IgG})$ in the blood after water intake. pre: before water intake, post: after water intake. The wilcoxon signed rank test was used for statistical analysis. $p<0.05$ : statistically significant, NS, not significant; Con, control group.

end of the study period $(p<0.05)$ (Figure 2 ), whereas no significant change was observed in the control group.

\section{DISCUSSION}

A steady intake of water, the body's major constituent, is important to maintain good health, as regulation of water balance affects physiology $[10,11]$. In this study, we found that water intake may improve anemia by increasing the hemoglobin index. In the experimental group, the increase in hemoglobin was not significant, although there were significant increases in $\mathrm{MCH}$ and $\mathrm{MCHC}$, indicating that water assists hemoglobin synthesis. Our findings are supported by Colombo et al., who found that a large number of water molecules are needed for allosteric regulation of hemoglobin, from the deoxygenated tense state to the oxygenated relaxed state [12]. Furthermore, water plays a role in the allosteric constant [13]. Therefore, a steady intake of water may influence hemoglobin synthesis, thereby alleviating anemia.

CVD is a major cause of death globally [14,15]. In recent studies, MPV, an indicator of platelet size and platelet activation, has been found to be a predictor of cardiovascular risk [3]. MPV has been found to be significantly higher in obese than in non-obese individuals, and an elevated MPV is associated with an increased risk of acute myocardial infarction [2,3]. In addition, in patients with hypertensive retinopathy, an elevated MPV was shown to correspond with increased severity of retinopathy [16]. Hs-CRP levels are used as an immunological marker of CVD risk [7]. In this study, hs-CRP levels did not decrease significantly, although the decrease was greater in the experimental group than in the control group. Based on these results, we conclude that a steady intake of water may diminish the risk of CVD by decreasing the MPV and, perhaps, by decreasing the concentration of hs-CRP.

IgG plays an important role in humoral immunity [9]. In a study of the association between water intake and immunity in pigs, consumption of oxygenated drinking water was associated with increased immune activity, demonstrated by proliferation of peripheral blood mononuclear cells and interleukin-1 $\beta$, an increase in the CD4+:CD8+ T-cell ratio, and boosted immune responses against bacterial infection [17]. In addition, consumption of oxygenated water was associated with an increase in the concentration of IgG and IgM in broiler chickens [18]. Generally, primary immune deficiencies are caused by antibody deficiencies, and IVIG comprised of pooled IgG antibodies is used to treat immunodeficiency diseases. Furthermore, IVIG is used to treat autoimmune and degenerative diseases [19,20]. Patients with autoimmune diseases that lead to autoantibody production, such as rheumatoid arthritis, systematic lupus erythematosus, and immunothrombocytopenia, have low blood concentrations of IgG; treatment with IVIG can suppress the autoimmune disease process via immune system modulation [8,21]. Therefore, the concentration of $\operatorname{IgG}$ in the blood is important for immunomodulatory responses. Water plays a role in transforming hemoglobin to the oxygenated relaxed state. Based on our results, we postulate that an increase in the proportion of oxygenated relaxed state of hemoglobin due to water consumption, may promote an increase in the concentrations of $\operatorname{IgG}$, thereby improving humoral immunity.

In this study, we also evaluated a variety of other parameters, including lipid profiles and the levels of liver enzymes, lipoprotein (a), fibrinogen, and vitamin D. 
However, except for the hematologic parameters, hs-CRP, IgG, and lipid profiles, no differences were observed in the other parameters. In terms of the lipid profiles, the low-density lipoprotein cholesterol, total cholesterol, and triglyceride did not change. However, high-density lipoprotein cholesterol increased, implying that a steady intake of water may protect the development of atherosclerosis, risk factor for CVD, although the increase was not significant (data not shown).

A limitation of this study was that the sample size was too small to verify the findings at a population level; some participants were excluded due to medication and insufficient water intake. Therefore, although this study suggests that a steady intake of water has beneficial effects on human health, additional studies with larger sample sizes are necessary to further elucidate its influences on physiological conditions. Nevertheless, these findings may provide useful guidance in health care.

In conclusion, a steady intake of water may reduce anemia and CVD risk by increasing hemoglobin synthesis and decreasing MPV; it may also enhance humoral immunity by increasing IgG levels.

\section{요 약}

물은 생체에 필수적인 성분이고 많은 생리학적 과정에 관련 되어 있음에도 불구하고 물을 꾸준히 충분하게 섭취하는 것이 혈액 성분에 어떤 영향을 미치는지에 대해서는 잘 알려져 있지 않다. 따라서 이 연구에서는 13 명의 정상 성인에게 물을 섭취하 게 한 후에 혈액학적, 고감도 $\mathrm{C}$ 반응성 단백질(hs-CRP), 면역글 로불린 $\mathrm{G}(\mathrm{IgG})$ 의 변화를 측정하였다. 4 명의 대조군은 물을 자 유롭게 마시게 하였고 9 명의 실험군은 시판되는 생수를 매일 2 $\mathrm{L}$ 씩 마시게 하였다. 2주 후에 혈액을 채취하여 검사한 결과, 혈 구 세포 수, 적혈구 용적률, 혈색소 수치는 증가했지만 유의성은 없었다 $(p>0.05)$. 그러나 평균 혈색소량 $(\mathrm{MCH})$ 과 평균 혈색소 농도 $(\mathrm{MCHC})$ 는 각각 의미 있게 증가하였고 $(p<0.05, p<0.01)$, 평균 혈소판 용적(MPV)은 의미 있게 감소하였다 $(p<0.05)$. 심 혈관 질환의 표지자로 쓰이는 면역학적인 검사항목인 hs-CRP 는 물 섭취 후에 감소하는 것으로 나타났으나 유의한 차이는 없 었다 $(p>0.05)$. 그러나 IgG의 농도는 물 섭취 전에 비해 상당히 유의성 있게 증가하는 결과를 나타냈다 $(p<0.05)$. 결론적으로,
꾸준히 충분하게 물을 섭취하면 혈색소 수치가 증가하여 빈혈 이 완화될 수 있고 혈소판 활성과 hs-CRP가 감소하여 심혈관 질환의 위험을 줄일 수 있다. 또한 체액성 면역 성분이 증가하여 면역 기능이 향샹될 수 있다.

Acknowledgements: This work was supported by the 2016 Gimcheon University Research Grant.

Funding: None

Conflict of interest: None

\section{REFERENCES}

1. Rodak BF Frisma GA, Keohane EM. Hematology: Clinical principles and applications. 4th ed. Missouri: Elesevier; 2012. p1-6.

2. Coban E, Ozdogan M, Yazicioglu G, Akcit F. The mean platelet volume in patients with obesity. Int J Clin Pract. 2005;59(8): 981-982.

3. Chu SG, Becker RC, Berger PB, Bhatt DL, Eikelboom JW, Konkle $\mathrm{B}$, et al. Mean platelet volume as a predictor of cardiovascular risk: a systematic review and meta-analysis. J Thromb Haemost. 2010;8(1):148-156.

4. Dantzer R, Kelley KW. Twenty years of research on cytokine-induced sickness behavior. Brain Behav Immun. 2007; 21(2):153-160.

5. Shanahan L, Bauldry S, Freeman J, Bondy CL. Self-rated health and C-reactive protein in young adults. Brain Behav Immun. 2014;36:139-146.

6. Koh JM, Khang YH, Jung CH, Bae S, Kim DJ, Chung YE, et al. Higher circulating hsCRP levels are associated with lower bone mineral density in healthy pre- and postmenopausal women: evidence for a link between systemic inflammation and osteoporosis. Osteoporos Int. 2005;16(10):1263-1271.

7. Soriano-Guillén L, Hernández-García B, Pita J, DomínguezGarrido N, Del Río-Camacho G, Rovira A. High-sensitivity C-reactive protein is a good marker of cardiovascular risk in obese children and adolescents. Eur J Endocrinol. 2008;159(1): R1-4.

8. Schwab I, Nimmerjahn F. Intravenous immunoglobulin therapy: how does IgG modulate the immune system? Nat Rev Immunol. 2013;13(3):176-189.

9. Kaneko Y, Nimmerjahn F, Ravetch JV. Anti-inflammatory activity of immunoglobulin $\mathrm{G}$ resulting from Fc sialylation. Science. 2006;313(5787):670-673.

10. Jéquier E, Constant F. Water as an essential nutrient: the physiological basis of hydration. Eur J Clin Nutr. 2010;64(2): 115-123.

11. Popkin BM, D'Anci KE, Rosenberg IH. Water, hydration, and health. Nutr Rev. 2010;68(8):439-458.

12. Colombo MF, Rau DC, Parsegian VA. Protein solvation in allosteric regulation: a water effect on hemoglobin. Science. 1992;256(5057):655-659.

13. Bulone D, San Biagio PL, Palma-Vittorelli MB, Palma MU. The 
role of water in hemoglobin function and stability. Science. 1993;259(5099):1335-1336.

14. Roth GA, Huffman MD, Moran AE, Feigin V, Mensah GA, Naghavi M, et al. Global and regional patterns in cardiovascular mortality from 1990 to 2013. Circulation. 2015;132(17):16671678.

15. Oksak GA, Golovanova IA. Contribution of mortality from cardiovascular disease to overall mortality. Wiad Lek. 2017;70(3 pt 1):449-455.

16. Bhatti AB, Ali F, Satti SA. Relationship of hypertensive retinopathy with mean platelet volume among hypertensive patients. Cureus. 2015;7(12):e422.

17. Jung BG, Lee JA, Lee BJ. Oxygenated drinking water enhances immune activity in pigs and increases immune responses of pigs during Salmonella typhimurium infection. J Vet Med Sci.
2012;74(12):1651-1655.

18. Shin D, Cho ESR, Bang HT, Shim KS. Effects of oxygenated or hydrogenated water on growth performance, blood parameters, and antioxidant enzyme activity of broiler chickens. Poult Sci. 2016;95(11):2679-2684.

19. Ballow M. Primary immunodeficiency disorders: antibody deficiency. J Allergy Clin Immunol. 2002;109(4):581-591.

20. Ramos-Medina R, Corbí AL, Sánchez-Ramón S. Intravenous immunoglobulin: immunomodulatory key of the immune system. Med Clin (Barc). 2012;139(3):112-117.

21. Imbach P, Barandun S, d'Apuzzo V, Baumgartner C, Hirt A, Morell A, et al. High-dose intravenous gammaglobulin for idiopathic thrombocytopenic purpura in childhood.Lancet. 1981; 1(8232):1228-1231. 